\title{
Constraints of Biosecurity Adoption on Beef Cattle Farms
}

\author{
Veronica Sri Lestari ${ }^{1}$, Sitti Nurani Sirajuddin ${ }^{1}$, Agustina Abdullah ${ }^{1}$
}

\begin{abstract}
Biosecurity is very important to be applied in the farm in order to prevent cattle from contagious diseases. The aim of this research was to know the level and constraints of biosecurity adoption by beef cattle farms in South Sulawesi. This research was conducted in 2017 in Luwu regency, South Sulawesi province. Total sample was 31 beef cattle farmers who were choosed through purposive sampling. Data on biosecurity adoption level included vaccination, sanitation and traffic arrangements. Data were obtained through observation and interview using questionnaire. There were 21 questions for the level of biosecurity adoption. If beef cattle farmers adopt biosecurity, the score was 1 , on the other hand, if beef cattle farmers do not adopt biosecurity, the score was 0 . To know the adoption barrier, Delphi method and Focus Discussion Group were used. Data were analyzed descriptively. The results showed that the adoption level of beef cattle breeders was categorized as "high adopter". Factors inhibiting the application of biosecurity to beef cattle farmers sequenced from the highest percentage were shortage of extension workers, shortage of veterinarian, lack of technical knowledge of animal husbandry and lack of capital.
\end{abstract}

Keywords: adoption, beef cattle farmers, biosecurity, constraints

\section{Introduction}

Beef cattle produce meat for the community. The growth of livestock population in Indonesia is slow because there are still pregnant cattle were slaughtered, beef cattle farmers used to traditional maintenance system. The ownership is between 23 heads per farmer, the community considers cattle as a savings that can be sold at any time. The Indonesian government has issued livestock policy and innovated livestock technology, improved management to increase cattle population. One of the important government policies in order to prevent transmission of infectious diseases is biosecurity. According to FAO (2008), biosecurity is the key to prevent the spread of disease and infections. Biosecurity is made up of three components: segregation, cleaning and disinfection.

Biosecurity practices consisted of isolation, traffic control and sanitation. Isolation prevents contact between animals within a controlled environment. Traffic control includes traffic onto one's operation and traffic patterns within one's operation. Sanitation addresses the disinfection of materials, people and equipment entering the operation and the cleanliness of the people and equipment in the operation (Sharma, 2010). Biosecurity measures in cattle farms consisted of animal movement, equipment sharing and companies and contractors visiting the farms (Brenan and Christley, 2012). Adoption is a mental process through which an individual passes from hearing about an

| ${ }^{1}$ Department of Socio-Economics, Faculty of Animal Science - Hasanuddin University Jl. Perintis Kemerdekaan Km. 10 Makassar 90245 South Sulawesi Province 
innovation to its adoption (Rogers, 1962 in Karki and Bauer, 2004). There are five adoption stages namely: awareness, interest, evaluation, trial and error, and the last is adoption (Ban and Hawkins, 1999).

The application of biosecurity and good livestock breeding has in fact experienced several obstacles. Some previous research proves that according to Channappagouda et al. (2016), inadequate knowledge on diseases of cattle and their control were perceived as the major constraints by the dairy farmers respectively in adoption of scientific animal breeding and health care practices.

According to Mutibvu et al. (2012) the most critical constraints to increase animal production were disease problems, feed and water shortages and inadequate extension service.

Ayoade and Akintonde (2012) argued that late adoption of innovations was due to irregular visits of extension agent. According to Gangasagare and Karanjkar (2009), numbers of farmers did not care to vaccinate and accept other health measures for their animals.

Ashraf at al. (2013) found that farmers do not have technological knowledge and they lack in resources to create interest toward technicality attainments. More importantly, role of Livestock Extension Field Staff was negligible. Brenan and Christley (2012) said that many beef cattle farmers are carried out infrequently or not at all. This may be due to many factors, including cost (in time and money), lack of proven efficacies of practices and lack of relevant education of veterinary surgeons, producers and other herd health specialists.

According to Adams and Yankyera (2015), diseases and pests menace, insufficient veterinary offices and animal health professionals were the major three constraints affecting animal health management in northern Ghana

Based on these facts, the researcher interested to conduct research on the level and constraints of biosecurity adoption in beef cattle farmers in Luwu regency, South Sulawesi province.

\section{Research Method}

The research was conducted in Luwu regency in 2017. Sample was 31 beef cattle farmers who were choosed purposively. To know the level of biosecurity adoption, observation and interview by using questionnaire were conducted. The questionnaire was consisted of vaccination, sanitation and traffic. Guttman scale was used in this research, if the answer was YES the score was 1, if the answer was NO, the score was 0.

The level of biosecurity adoption was calculated by adoption index (Karthikeyan, 1994 in Rahman, 2007):

Adoption index $=\frac{\text { Respondent total score }}{\text { Total possible score }} \times 100$

Depending upon the extent of adoption of biosecurity measures, the respondents were categorized as follows:

(1). Low adopter (up to $33 \%$ )

(2). Partial adopters $(34-66 \%)$

(3). High adopters $(67-100 \%)$

To know constraints of biosecurity adoption, data were collected through Delphi 
method and Forum Group Discussion. The Delphi method is a long range of forecasting techniques that elicits, refines, and refers to the collective opinions and expertise of the expert panel (Gupta and Clarke, 1996). According to Dilworth (1992), the Delphi Method is a systematic tool for obtaining consensus from an expert group (panel). Each member of the expert group is preserved independently, so that each member is free to express an opinion. The Delphi method is expected to get opinions, consensus or problems qualitatively. The expert group coordinator will usually ask a problem to each group member by passing the questionnaire. The Delphi method is considered appropriate to encompass opinion for objective vision formulation with consideration when subjective factors are expected to be very important or when accurate quantitative data are difficult to obtain. The goal is to reduce the negative effects of interaction groups and to gain the most reliable consensus of the opinions of a group of experts (Gupta and Clarke, 1996; Dalkey and Helmer, 1963; Dalkey, 1969). The hallmark of the Delphi Method is that all participants are treated as unknown persons (Schroeder, 2000). It aims to reduce the influence of feeling hesitant or offensive to other participants who are considered to have influence or a higher position. Ciptomulyo (2001) also characterizes the Delphi Method: (1) the ability to accommodate individual subjective opinions on an iterative basis and the presence of controlled feedback in the assessment of group responses, (2) the anonymous nature of the survey allows for free expression of opinion and no dominance effect, and (3) all respondents are actively involved at the beginning of the process and survey round. According to Barry et al. (2000), there were three groups of participants in the Delphi Method: (1) the decision maker is a group of experts as a panel, (2) the coordinator of one or more tasks preparing, distributing, tabulating and summarizing it during the decision process lasts, and (3) the respondents are a number of people whose decisions are assessed and considered. In practice, respondents are required if decision makers need to get input before making a decision. Conversely, if the decision maker has been able to make decisions based on ability, then the respondent is no longer needed. Therefore, this Delphi method more often involves two groups only, namely decision makers and coordinators. The approach can be done by interviewing directly or using electronic mail and then comparing and analyzing the responses of the experts, and then reporting back to the participants for a response (Graham et al., 2003).

In this research, Delphi method was used through three times meeting. Constraints of biosecurity adoption were asked to beef cattle farmers at the first meeting. The second meeting was conducted with the same question as the question at the first meeting after a week. The last meeting was stopped after the constraints of biosecurity adoption remain the same as the second meeting. The third most frequent answers were identified as the constraints of biosecurity adoption of beef cattle farmers.

\section{Results and Discussion}

\subsection{Characteristic of Respondents}

As can be seen in Table 1. mayority of respondents were men $(83.87 \%)$ with the average age was 43.49 year. Their education was low because the just spend for 7.839 year at school. The number of their family on average was categorize as small family. The 
number of beef cattle belong to respondents on average was small (4.355 head) and their experience on handling beef cattle was good enough (10.065 year).

Table 1. Characteristics of Beef Cattle Farmers

\begin{tabular}{lccc}
\hline Characteristics & Mean & Standard Deviation & Percentage \\
\hline Sex $\quad$ Male & & & 83.87 \\
a. Female & & & 16.13 \\
b. & 43.49 & 11.598 & \\
Age (year) & 7.839 & 2.282 & \\
Education (year) & 4.419 & 1.566 & \\
Family size (person) & 4.355 & 2.402 & \\
Number of beef cattle (head) & 10.065 & 7.215 & \\
Experience (year) & &
\end{tabular}

\subsection{Biosecurity Adoption}

As can be seen in Table 2. the level of biosecurity adoption of beef cattle farmers was categorize as "high", because on average the percentage was higher than $66 \%$. It was $85.21 \%$. Meaning that beef cattle farmers in Walenrang district, Luwu regency adopt biosecurity. The highest biosecurity adoption was traffic in pens $(99.63 \%)$ which included animal traffic, feeding equipment, vehicle and people traffic followed by sanitation (96\%), and the lowest biosecurity adoption was disease prevention and vaccination $(60 \%)$.

Table 2. Biosecurity Adoption

\begin{tabular}{|c|c|c|c|}
\hline $\mathrm{No}$ & Variables & Score & Percentage \\
\hline \multirow[t]{2}{*}{1} & $\begin{array}{l}\text { Disease prevention and vaccination } \\
\text { a. Know the health history of the herds from which cattle are purchased } \\
\text { b. Transport animals in clean vehicles } \\
\text { c. Loading area is located at the perimeter of the operation } \\
\text { d. Dead animal pickup area located so rendering trucks do not contaminate the operation } \\
\text { e. Keep a record of visitors to the operation }\end{array}$ & $\begin{array}{l}1.0 \\
0.6 \\
0.2 \\
1.0 \\
0.2\end{array}$ & $\begin{array}{c}20 \\
12 \\
4 \\
20 \\
4\end{array}$ \\
\hline & Total & 3.0 & 60 \\
\hline \multirow[t]{2}{*}{2.} & $\begin{array}{l}\text { Sanitation } \\
\text { a. Attempt to prevent manure contamination of feed and equipment used orally } \\
\text { b. Clean equipment used orally between animals } \\
\text { c. Regularly evaluate the activities on my operation to assess the potential for } \\
\text { contaminating cattle } \\
\text { d. If manure accidently contaminates feed or water, an immediate remedy is provided }\end{array}$ & $\begin{array}{c}1.0 \\
1.0 \\
0.83\end{array}$ & $\begin{array}{l}25 \\
25 \\
20\end{array}$ \\
\hline & Total & 3.83 & 96 \\
\hline \multirow[t]{3}{*}{3} & $\begin{array}{l}\text { Traffic } \\
\text { a. Attempt to prevent cross contamination between healthy and sick/dead cattle } \\
\text { b. Have a control program for outside animals which could spread disease (rodents, etc) } \\
\text { c. Use different equipment to feed and to clean pens or completely clean between use. } \\
\text { d. Never step in the feed bank } \\
\text { e. Never leave manure-heuling equipment in pens with different groups of animals } \\
\text { f. Clean contaminated vehicles and equipment before use around healthy cattle } \\
\text { g. Routinely clean and disinfect feeding equipment and cattle handling equipment } \\
\text { h. Routinely clean and disinfect equipment used to medicate cattle } \\
\text { i. Limit people's access to cattle pens, feed mixing and storage area and treatment area } \\
\text { j. Facilities provide a clean area for restraint, treatment and isolation of sick cattle } \\
\text { k. Handle highest health status animal first (young calves, healthy older cattle and sick } \\
\text { animal last) } \\
\text { l. Clean contaminated vehicles and equipment before use around healthy cattle }\end{array}$ & $\begin{array}{c}0.97 \\
0.7 \\
0.8 \\
0.37 \\
0.5 \\
0.8 \\
0.7 \\
0.7 \\
0.17 \\
1.0 \\
0.4 \\
0.7 \\
\end{array}$ & $\begin{array}{c}12.4 \\
8.9 \\
10.2 \\
4.73 \\
6.4 \\
10.2 \\
8.9 \\
8.9 \\
2.2 \\
12.8 \\
5.1 \\
\\
8.9 \\
\end{array}$ \\
\hline & Total & 7.81 & 99.63 \\
\hline & Average & & 85.21 \\
\hline
\end{tabular}




\subsection{Constraints of Biosecurity Adoption}

Table 3. Constraints of Biosecurity Adoption by Beef Cattle Farmers

\begin{tabular}{clc}
\hline No & Constraints & Frequency $(\%)$ \\
\hline 1 & Lack of extension worker & 38.0 \\
2 & Lack of veterinarian & 29.0 \\
3 & Lack of knowledge & 25.0 \\
4 & Lack of capital & 8.0 \\
& Total & 100.0 \\
\hline
\end{tabular}

Table 3 showed that the most constraints of biosecurity adoption by beef cattle farmers was lack of extension worker. One extension worker must cover a big area with many farmer groups. Beside that the condition of land was mountainous. It takes time to go to farmer group using motor bike. This research agree with that of Mutibvu et al. (2012), Ashraf at al. (2013), Ayoade and Akintonde (2012).

The second constrain was lack of veterinarian. This was the same as the first constraint. Most of veterinarian worked at Animal Husbandry Service in Luwu province. Beside the long distance from province to rural area, the number of veterinarian was also small. This agree with that of Adams and Yankyera (2015) who argued that insufficient veterinary offices was the mayor constraint of ruminant farmers' decision to participate in veterinary services in Northern Ghana.

The third constraint was lack of knowledge especially about cattle diseases and how to prevent cattle diseases. This is related to the low level of education of respondents and the lack of training and extension, especially on animal health. This research was supported by Brenan and Christley (2012), Gangasagare and Karanjkar (2009), Channappagouda et al. (2016).

The fourth constraint was lack of capital. The farmers do not have capital to make pens according to the requirements of good maintenance management. The pens were made from wood. Beef cattle were removed from the garden from morning until late afternoon for grassing. During the evening, beef cattle went back to their pens. This agree with that of Ahmed et al. (2016).

\section{Conclusion}

Based on this research, it can be concluded that eventhough the level of biosecurity adoption was categorized as high adopter, beef cattle farmers faced constraints on biosecurity adoption such as lack of extension worker followed by lack of veterinerian, lack of knowledge and lack of capital.

\section{References}

Adams, F. and K. O. Yankyera. 2015. Determinants of small ruminant farmers decision to participate in veterinary services in Northern Ghana. Journal of Veterinary Medicine and Animal Health. Vol 7(5): 193-204.

Ahmed, K., Tamir, B., Mengistu, A. 2016. Constraints, Opportunities and Challenges of Cattle Fattening Practices in Urban and Peri-Urban Kebeles of Dessie Town, Ethiopia. J Fisheries Livest Prod 4: 203. 
Ashraf, S. M. Iftikhar, G.A. Khan, B. Shahbaz and I. Ashraf. 2013. Performance evaluation of the dairy farmers regarding adoption of precise dairy farming practices in the Punjab, Pakistan. African Journal of Agricultural Research. Vol. 8(29), pp. 4074-4080.

Ayoade A.R Akintonde J.O. 2012. Constraints to adoption of agricultural innovations among women farmers in Isokan Local Government Area, Osun State. International Journal of Humanities and Social Science Vol. 2 No. 8 [Special Issue - April 2012] 57

Barry, R., Stair, R.M. dan Hanna, M.E. 2000. Quantitative Analysis for Management. Prentice Hall, New Jersey.

Brenan, M.L. and R.M. Christley. 2013. Cattle producers' perception of biosecurity. BMC Veterinary Research. 9 (71): 1 - 8.

Buhman, M., G. Dewell and D. Griffin. 2000. Biosecurity Basic for Cattle Operation and Good Management Practices (GMP) for Controlling Infectious Diseases. NebGuide. University of Nebrasca. Lincoln Extension. Institute of Agriculture and Natural Resources. Nebrasca.

Channappagouda, B., Deekshit, G.V.1, Bharadwaja Krishna and Mahesh S D. 2016. Constraints in adoption of scientific animal breeding and health care practices-farmers'point of view. International Journal of Science, Environment and Technology, Vol. 5(5): 3435 - 3439

Ciptomulyo, U. 2001. Integrasi metode Delphi dan Prosedur Analisis Hierarkhis (AHP) untuk identifi kasi dan penetapan prioritas objektif/kriteria keputusan. Jurnal IPTEK 12: 42-52.

Dalkey, N. dan Helmer, O. 1963. An experimental application of the Delphi method to the use of experts. Journal of the Institute of Management Science 9 (3): 458-467.

Dalkey, N.C. 1969. The Delphi Method: an Experimental Study of Group Opinion. Research Paper RM5888-PR. The Rand Corporation, June.

Dilworth, J.B. 1992. Operation Management: Design, Planning and Control for Manufacturing and Services, Mc. Graw Hill, New York.

FAO. 2008. Biosecurity for Highly Pathogenic Avian Influenza. Animal Production Health Paper. Rome. Italy.

Gangasagare, P.T. and L.M. Karanjkar. 2009. Constraints in adapting animal husbandry practices by the dairy farmers in the marathwada region of Maharashtra. Veterinary World, Vol.2(9):347-349.

Graham, B., Regher, G. dan Wright, J.G. 2003. Delphi as a method to establish consensus for diagnostic criteria. Journal on Clinical Epidemiologi 56: 1150-1156.

Gupta, U. G. dan Clarke, R. E. 1996. Theory and Application of The Delphi Technique: A Bibliography (1975-1994). Technological Forecasting and Social Change 53(2): 185- 211.

Karki, L.B. and S. Bauer. 2004. Technology adoption and household food security. Analysing factors determining technology adoption and impact of project intervention: A case of smallholder peasants in Nepal. The Deutscher Tropentag. 5-7 October 2004, Humboldt University Berlin.

Mutibvu, T., Maburutse, B. E., Mbiriri, D. T., and Kashangura, M. T. 2012. Constraints and opportunities for increased livestock production in communal areas: A case study of Simbe, Zimbabwe. Livestock. Research for Rural Development. Volume 24, Article \#165. Retrieved February 3, 2018, from http://www.lrrd.org/lrrd24/9/muti24165.htm

Schroeder, R.G. 2000. Operation Management: Contemporary Concepts and Cases. Mc Graw-Hill, New York.

Sharma, B. 2010. Poultry production, management and bio-security measures. The Journal of Agriculture and Environment Vol:11, pp: 120-125.

Van den Ban, A.W. and H.S. Hawkins. 1999. Penyuluhan Pertanian. Penerbit Kanisius. Yogyakarta. 